\title{
Response of Wheat on Seed Rate and Irrigation Levels
}

\author{
Gebeyehu Tegenu \\ Ethiopian Agricultural Research Institute Debre Zeit Agricultural Research Center \\ P.O.Box 32, Debre Zeit, Ethiopia
}

\begin{abstract}
This paper was prepared by reviewing documents and research findings from studies conducted focusing on interaction effect of seed rate and irrigation level on wheat crops. The temporal and spatial coverage of the research findings was between 2009 and 2016. Approaches followed on the response of crops to irrigation level and seed rates were through reviewing journals from websites and research output reports. In this review, achievements of different seed rates for different irrigation levels on crops under diverse agro-ecologies are highlighted based on the current knowledge from available sources. Research findings revealed that interactive effect of seed rates and amount of irrigation water had significantly improved yield of crops. Therefore, based on the current findings, application of seed rate increased for irrigated crops the yield also increased and be combined with the required amount of irrigation water and seed rate.
\end{abstract}

Keywords: seed rate, Wheat, irrigation level

DOI: $10.7176 / \mathrm{JRDM} / 72-02$

Publication date: January $31^{\text {st }} 2021$

\section{Introduction}

There is an increasing need to produce more food in order to feed the ever increasing population in the world. This is also true for cereal production. As it is not possible to increase the land cultivated, the only solution and option are to increase the grain yield and productivity. Ethiopia's agriculture system constitutes $46 \%$ of gross national production, employs $85 \%$ of its population, and creates $75 \%$ of export commodity value (FDRE, 2013). Despite its large scale, the agricultural sector is largely formed by smallholder subsistence farms burdened by dependence on erratic rain-fed systems. In all, smallholders account for $96 \%$ of total area cultivated (Taffesse et al., 2011). Ethiopia's rain dependent agricultural system is particularly vulnerable to shifts in climate and weather, with less than $3 \%$ of households having access to irrigation (or less than $1 \%$ of cereal acreage) (Mann and Warner, 2015, Taffesse et al., 2011). These vulnerabilities are further exaggerated by extensive use, land degradation, and household poverty.

Now a day's irrigation development is increasingly implemented in Ethiopia more than ever to supplement the rain-fed agriculture. It aims to increase agricultural productivity and diversify the production of food and raw materials for agro-industry as well as to ensure that the agriculture to play a pivotal for driving the economic development of the country.The major crop category that included cereals, pulses and oil seeds, which not only constituted the major food crops for the majority of the country's population but also served as a source of income at household level and a contribute for the country's foreign currency earnings, among others.

Within the category of Grain crops, Cereals are the major food crops both in terms of the area they are planted and volume of production obtained. They are produced in larger volume compared with other crops because they are the principal staple crops. Cereals are grown in all the regions with varying quantity (CSA, 2017/18). Out of the total grain crop area, $80.71 \%$ the area was under cereals. Tef, maize, sorghum and wheat took up of the grain crop area, respectively. Cereals contributed $87.48 \%$ ) of the grain production. Maize, teff, wheat and sorghum made up $27.43 \%, 17.26 \%, 15.17 \%$ and $16.89 \%$ of the grain production, respectively (CSA, 2017/18).

Ethiopia is the second largest producer of wheat in Sub-Saharan Africa. In Ethiopia, wheat is one of the major cereal crops grown between 6 and $14 \mathrm{o} \mathrm{N}$ latitudes; and between 35 and $42 \mathrm{oE}$ longitude ranging in altitude from $1500 \mathrm{~m}$ to $3200 \mathrm{~m}$. The most suitable regions, however, fall between $1900 \mathrm{~m}$ and $2700 \mathrm{~m}$. The current total area of production of both durum (Triticum turgidum var. durum) and bread wheat (Triticum aestivum) is more than about 861,100 hectares (CSA, 1988)). Other sources, however, estimate the total area to be 1.2 to 1.5 million hectares. This area is limited to the intermediate altitudes and the highlands despite a potential for irrigated wheat production in the lowlands. In area coverage, durum and bread wheat types hold equal proportions according to a recent survey by a group of wheat researchers. Bread wheat production, nevertheless, is on the increase. Other Ethiopian wheat species are also cultivated, but to a lesser extent. An example is emmer wheat (Triticum dicoccum). Ethiopia is one of the very few countries where Triticum dicoccum is still under cultivation. Other species like Triticum polonicum and Triticumaethiopicum are also grown in mixtures with other wheat species.

Seed rate is the most important agronomic aspect. Seed rate is playing a vital role for optimum cereal plant densities which is a pre-requisite for increased seed yield. It influences the yield and yield attributes of cereals.

Yursel, (2009) reported under irrigation condition lower number of plants $\mathrm{m}^{-2}$ and number of spike $\mathrm{m}^{-2}$ are significantly higher grain yield. In the seed rate experiment the lowest seed rate produced the highest grain yields 
spike. The seed rate of the highest value was obtained with the lowest seeding rate.

The rain-fed Agriculture of our Country cereal crops of seed rate is determined by different investigation. But in irrigated Agriculture still now we used the rain fed cereals seed rate. From the experiences the use of the rainfed packages to irrigated Agriculture is not recommended due to seed extravagance especially when the cereal crops are planted in rows.

In Ethiopia most farmers are producing cereal crops. So determinations of seed rate and fertilizer levels are useful under Irrigated Agriculture in order to increase yield and yield productivity of cereals. However, compiling the available research finding on seed rate recommendation for Wheat crops in irrigated agriculture is essential. Therefore, a review of different research outputs was conducted on Response of Wheat on seed rate and irrigation levels for efficient water and seed rate management and to make available information and technologies for user under irrigated agriculture. In this review, achievements of seed rates for Wheat crops are highlighted based on the current knowledge from available sources. Finally my recommendation was the seed rate of Wheat on irrigated Agriculture more difference from rain -fed agriculture. Still know in our Country do not conducted such experiment.

\section{MATERIALS AND METHODS}

Different research outputs on Response of Wheat on seed rate and irrigation levels were reviewed. This includes journals from online websites using www.goole.com search.

\section{RESULTS AND DISCUSSION}

Different seed rate and irrigation levels have a significant improvement on wheat yield indifferent research findings. Kabir et al. (2009) reported that the tallest plant $(82.36 \mathrm{~cm})$ was found from the seed rate of $140 \mathrm{~kg} \mathrm{ha}^{-1}$ and the shortest plant $(77.80 \mathrm{~cm})$ was found for the seed rate of $100 \mathrm{~kg} \mathrm{ha}^{-1}$ and also the highest number of total tillers plant ${ }^{1}$ (8.99), effective tillers plant ${ }^{-1}$ (3.49) was recorded from the seed rate of $140 \mathrm{~kg} \mathrm{ha}^{-1}$ and the lowest number of total tillers plant ${ }^{-1}(8.27)$, effective tillers plant ${ }^{-1}(2.48)$ was found from the seed rate of $100 \mathrm{~kg} \mathrm{ha}^{-1}$. The results showed that the highest grain yield $\left(2.82 \mathrm{t} \mathrm{ha}^{-1}\right)$ was obtained by the seed rate of $140 \mathrm{~kg} \mathrm{ha}^{-1}$, because of higher total tillers plant $^{-1}$, effective tillers plant ${ }^{-1}$. Based on irrigation level the highest grain yield $\left(3.30 \mathrm{tha}^{-1}\right)$ was produced by one irrigation applied at CRI stage and the lowest $\left(1.77 \mathrm{tha}^{-1}\right)$ was produced by control treatment which was statically similar to three irrigations applied at CRI, panicle initiation and grain filling stages. The study revealed that the maximum seed rate and application of full irrigation water obtained high yield of wheat.

On the other hand the highest number of non-effective tillers plant ${ }^{-1}(1.17)$ was found from the seed rate of $100 \mathrm{~kg} \mathrm{ha}^{-1}$ and the lowest $(0.95)$ was recorded for the seed rate of $140 \mathrm{~kg} \mathrm{ha}^{-1}$ which is statistically similar to the seed rate of $120 \mathrm{~kg} \mathrm{ha}^{-1}$.

Since the amount of soil moisture and seed rate have an interaction effect. The interaction between seed rate and irrigation level influenced significantly all the plant characters except plant height, spikelets spike ${ }^{-1}$ and $1000-$ grains weight. Most of the time the availability of adequate amount of water at the optimum depletion level leads to higher use efficiency of seed and vice versa. Moreover, adequate moisture content of the soil could lead to sufficient seed germination and productivity in soil.

Additionally Kabir et al. (2009) reported that the combination result of irrigation level and seed rate the highest number of total tillers plant ${ }^{-1}(9.18)$ was recorded from the seed rate of $140 \mathrm{~kg} \mathrm{ha}^{-1}$ combined with two irrigations applied at CRI and panicle initiation stages which was statistically similar with the seed rate of $160 \mathrm{~kg}$ $\mathrm{ha}^{-1}$ and two irrigations applied at CRI and panicle initiation stages and for the seed rate of $140 \mathrm{~kg} \mathrm{ha}^{-1}$ and one irrigation applied at CRI stage.. Among the treatments combination, the highest grain yield $\left(3.70 \mathrm{t} \mathrm{ha}^{-1}\right)$ was found from the seed rate of $140 \mathrm{~kg} \mathrm{ha}^{-1}$ combined with one irrigation applied at CRI stage. The lowest grain yield (1.55t $\mathrm{ha}^{-1}$ ) was found from the seed rate of $100 \mathrm{~kg} \mathrm{ha}^{-1}$ and control treatment. The highest straw yield $\left(4.50 \mathrm{t} \mathrm{ha}^{-1}\right) \mathrm{was}$ observed from the seed rate of $120 \mathrm{~kg} \mathrm{ha}^{-1}$ combined with one irrigation applied at CRI stage. The lowest straw yield $\left(2.90 \mathrm{t} \mathrm{ha}^{-1}\right)$ was observed from the seed rate of $160 \mathrm{~kg} \mathrm{ha}^{-1}$ combined with three irrigation applied at CRI, panicle initiation and grain filling stages. The highest harvest index (45.91\%) was observed from the seed rate of $140 \mathrm{~kg} \mathrm{ha}^{-1}$ combined with one irrigation applied at CRI stage. The lowest harvest index $(34.83 \%)$ was obtained from the use of seed rate of $100 \mathrm{~kg} \mathrm{ha}^{-1}$ with no irrigation applied. From the results of the present study it may, therefore be concluded that the seed rate of $140 \mathrm{~kg} \mathrm{ha}^{-1}$ with one irrigation given at CRI stage may be practiced for better performance of wheat yield.

Similarly, Shah et al. (2016) reported that the irrigation levels and seed rates had significant effect on grain yield of wheat. Regarding seed rates, maximum grain yield (3160 kg ha-1) was produced when plots were seeded with $120 \mathrm{~kg}$ ha-1, while minimum grain yield (2437 kg ha-1) was noted with $60 \mathrm{~kg}$ ha-1 seed rate. The maximum grain yields (3130 kg ha-1) was recorded in plots treated with $470 \mathrm{~mm}$ water, while minimum grain yield (2417 kgha-1) was recorded when $120 \mathrm{~mm}$ water was given to the plot.

While the number of grains spike- 1 of wheat significantly influenced by different irrigation levels and seed rates. Maximum grains spike-1 (64) were recorded from plots treated with $470 \mathrm{~mm}$ water and less grains spike-1 
(51) were recorded when $120 \mathrm{~mm}$ water was given. The data also revealed that in seed rates, more grains spike-1 (62) were produced when plots were seeded with $120 \mathrm{~kg}$ ha-1 seed rate (SR4), whereas less number of grains spike-1 (54) were noted with $60 \mathrm{~kg}$ ha-1 seed rate (SR1). The data further showed that interaction between irrigation levels and seed rates (IL x SR) was found significant. Maximum number of grains spike-1 were noted when water was used at the rate of $470 \mathrm{~mm}$ and seeded with $120 \mathrm{~kg}$ ha- 1 while minimum number of grains spike1 were recorded from plots when $120 \mathrm{~mm}$ water was applied and $60 \mathrm{~kg}$ ha- 1 seed rate used.

Table 1.Effect of seed rate on the yield and yield performance of wheat CV

\begin{tabular}{|c|c|c|c|c|c|c|c|c|c|c|}
\hline & Seed rate $(\mathrm{kg} / \mathrm{ha})$ & $\begin{array}{l}\text { Plant } \\
\text { height }(\mathrm{cm})\end{array}$ & $\begin{array}{l}\text { Total } \\
\text { tillers } \\
\text { plant } \\
1\end{array}$ & $\begin{array}{l}\text { Effective } \\
\text { tillers } \\
\text { plant }{ }^{-1} \\
\text { (no) }\end{array}$ & $\begin{array}{l}\text { Non- } \\
\text { effective } \\
\text { tillers } \\
\text { plant } \\
{ }^{1} \text { (no) } \\
\end{array}$ & $\begin{array}{l}\text { Spikelets } \\
\text { spike }-1 \\
\text { (no) }\end{array}$ & $\begin{array}{l}1000- \\
\text { grain } \\
\text { weight } \\
\text { (g) }\end{array}$ & $\begin{array}{l}\text { Grain } \\
\text { yield } \\
(\mathrm{t} / \mathrm{ha})\end{array}$ & $\begin{array}{l}\text { Straw } \\
\text { yield } \\
(\mathrm{t} / \mathrm{ha})\end{array}$ & $\begin{array}{l}\text { Harvest } \\
\text { index } \\
(\%)\end{array}$ \\
\hline \multirow{7}{*}{ 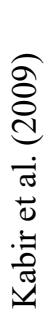 } & 100 & $77.80^{\mathrm{d}}$ & $8.27^{b}$ & $2.48^{\mathrm{d}}$ & $1.17^{\mathrm{a}}$ & $13.85^{\mathrm{c}}$ & 32.91 & $2.15^{\mathrm{d}}$ & $3.26^{\mathrm{c}}$ & $39.12^{\mathrm{c}}$ \\
\hline & 120 & $80.42^{b}$ & $8.84^{\mathrm{a}}$ & $2.98^{b}$ & $0.99^{\mathrm{c}}$ & $14.80^{\mathrm{b}}$ & 32.90 & $2.57^{b}$ & $3.57^{b}$ & $41.28^{\mathrm{b}}$ \\
\hline & 140 & $82.36^{\mathrm{a}}$ & $8.99^{a}$ & $3.49^{\mathrm{a}}$ & $0.95^{\mathrm{c}}$ & $15.50^{\mathrm{a}}$ & 33.48 & $2.82^{\mathrm{a}}$ & $3.73^{\mathrm{a}}$ & $42.43^{\mathrm{a}}$ \\
\hline & 160 & $79.46^{\mathrm{c}}$ & $8.76^{\mathrm{a}}$ & $2.71^{\mathrm{c}}$ & $1.09^{\mathrm{b}}$ & $14.34^{\mathrm{bc}}$ & 33.45 & $2.38^{\mathrm{c}}$ & $3.27^{\mathrm{c}}$ & $40.94^{\mathrm{b}}$ \\
\hline & $\begin{array}{ll}\text { Level } & \text { of } \\
\text { significance } & \\
\end{array}$ & $* *$ & $* *$ & $* *$ & $* *$ & $* *$ & NS & $* *$ & $* *$ & $* *$ \\
\hline & SX & 0.32 & 0.10 & 0.04 & 0.02 & 0.21 & 0.26 & 0.02 & 0.05 & 0.37 \\
\hline & $\mathrm{CV}(\%)$ & 3.71 & 6.28 & 6.50 & 11.97 & 4.22 & 1.54 & 4.39 & 3.88 & 2.47 \\
\hline
\end{tabular}

In a column figures having common letter(s) do not differ significant as per DMRT. ** indicates $1 \%$ level of probability, ${ }^{\mathrm{NS}}$ indicates not significant

Table 2.Effect of Irrigation on yield and yield performance of wheat CV.

\begin{tabular}{|c|c|c|c|c|c|c|c|c|c|c|}
\hline & $\begin{array}{l}\text { Level of } \\
\text { Irrigation }\end{array}$ & $\begin{array}{l}\text { Plant } \\
\text { height }(\mathrm{cm})\end{array}$ & $\begin{array}{l}\text { Total } \\
\text { tillers } \\
\text { plant }^{-1}\end{array}$ & $\begin{array}{l}\text { Effective } \\
\text { tillers } \\
\text { plant }^{-1} \\
\text { (no) }\end{array}$ & $\begin{array}{l}\text { Non- } \\
\text { effective } \\
\text { tillers } \\
\text { plant }^{-} \\
{ }^{1} \text { (no) }\end{array}$ & $\begin{array}{l}\text { Spikelets } \\
\text { spike }{ }^{-1} \\
\text { (no) }\end{array}$ & $\begin{array}{l}\text { 1000- } \\
\text { grain } \\
\text { weight } \\
\text { (g) }\end{array}$ & $\begin{array}{l}\text { Grain } \\
\text { yield } \\
(\mathrm{t} / \mathrm{ha})\end{array}$ & $\begin{array}{l}\text { Straw } \\
\text { yield } \\
(\mathrm{t} / \mathrm{ha})\end{array}$ & $\begin{array}{l}\text { Harvest } \\
\text { index } \\
(\%)\end{array}$ \\
\hline \multirow{7}{*}{ 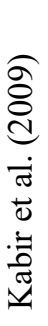 } & I0 & $77.07^{\mathrm{d}}$ & $8.18^{\mathrm{c}}$ & $2.43^{c}$ & $1.42^{\mathrm{a}}$ & 13.88 & 32.97 & $1.77^{\mathrm{c}}$ & $2.99^{c}$ & $37.06^{c}$ \\
\hline & I1 & $82.33^{\mathrm{a}}$ & $8.99^{a}$ & $3.31^{\mathrm{a}}$ & $0.61^{\mathrm{d}}$ & 15.70 & 33.17 & $3.30^{\mathrm{a}}$ & $4.09^{a}$ & $44.67^{\mathrm{a}}$ \\
\hline & $\mathrm{I} 2$ & $80.93^{b}$ & $9.07^{\mathrm{a}}$ & $3.22^{\mathrm{a}}$ & $0.97^{\mathrm{c}}$ & 15.14 & 33.15 & $2.94^{b}$ & $3.74^{\mathrm{b}}$ & $43.37^{\mathrm{a}}$ \\
\hline & I3 & $79.71^{\mathrm{c}}$ & $8.62^{b}$ & $2.69^{b}$ & $1.20^{\mathrm{b}}$ & 13.77 & 33.15 & $1.90^{c}$ & $3.00^{\mathrm{c}}$ & $38.69^{b}$ \\
\hline & $\begin{array}{l}\text { Level of } \\
\text { significance }\end{array}$ & $* *$ & $* *$ & $* *$ & $* *$ & $* *$ & NS & $* *$ & $* *$ & $* *$ \\
\hline & SX & 0.28 & 0.07 & 0.06 & 0.04 & 0.45 & 0.28 & 0.04 & 0.03 & 0.43 \\
\hline & $\mathrm{CV}(\%)$ & 3.71 & 6.28 & 6.50 & 11.97 & 4.22 & 1.54 & 4.39 & 3.88 & 2.47 \\
\hline
\end{tabular}

In a column figures having common letter(s) do not differ significant as per DMRT. ** indicates $1 \%$ level of probability, ${ }^{\mathrm{NS}}$ indicates not significant

$\mathrm{I}_{\mathrm{o}}=$ no irrigation i.e. control

$\mathrm{I}_{1}=$ one irrigation given at Crown Root Initiation (CRI) stage

$\mathrm{I}_{2}=$ two irrigation given at CRI and panicle initiation stages

$\mathrm{I}_{3}=$ three irrigation given at CRI, panicle initiation and grain filling stages. 
Table 3. Interaction effect of seed rate and irrigation on the yield and yield performance of wheat

\begin{tabular}{|c|c|c|c|c|c|c|c|c|c|c|}
\hline & $\begin{array}{l}\text { Interaction } \\
\text { (Seed rate } \times \\
\text { Irrigation) }\end{array}$ & $\begin{array}{l}\text { Plant } \\
\text { height }(\mathrm{cm})\end{array}$ & $\begin{array}{l}\text { Total } \\
\text { tillers } \\
\text { plant }^{-1}\end{array}$ & $\begin{array}{l}\text { Effective } \\
\text { tillers } \\
\text { plant }^{-1} \\
\text { (no) }\end{array}$ & $\begin{array}{l}\text { Non- } \\
\text { effective } \\
\text { tillers } \\
\text { plant } \\
1 \text { (no) }\end{array}$ & $\begin{array}{l}\text { Spikelets } \\
\text { spike }{ }^{-1} \\
\text { (no) }\end{array}$ & $\begin{array}{l}1000- \\
\text { grain } \\
\text { weight } \\
\text { (g) }\end{array}$ & $\begin{array}{l}\text { Grain } \\
\text { yield } \\
(\mathrm{t} / \mathrm{ha})\end{array}$ & $\begin{array}{l}\text { Straw } \\
\text { yield } \\
(\mathrm{t} / \mathrm{ha})\end{array}$ & $\begin{array}{l}\text { Harvest } \\
\text { index } \\
(\%)\end{array}$ \\
\hline \multirow{20}{*}{ 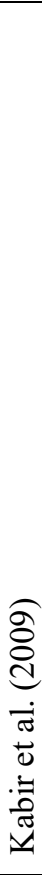 } & $\mathrm{S}_{1} \mathrm{I}_{0}$ & 74.50 & $7.75^{\mathrm{d}}$ & $2.00^{\mathrm{j}}$ & $1.50^{\mathrm{a}}$ & 13.15 & 33.30 & $1.55^{1}$ & $2.90^{\mathrm{h}}$ & $34.83^{\mathrm{i}}$ \\
\hline & $\mathrm{S}_{1} \mathrm{I}_{1}$ & 80.23 & $8.88^{\mathrm{ab}}$ & $3.00^{\mathrm{def}}$ & $0.77^{\text {gh }}$ & 15.00 & 33.58 & $2.85^{\mathrm{e}}$ & $3.68^{\mathrm{def}}$ & $43.64^{\mathrm{abc}}$ \\
\hline & $\mathrm{S}_{1} \mathrm{I}_{2}$ & 78.89 & $8.95^{\mathrm{ab}}$ & $2.60^{\mathrm{gh}}$ & $1.10^{\mathrm{de}}$ & 14.25 & 32.32 & $2.55^{\mathrm{f}}$ & $3.50^{\mathrm{efg}}$ & $42.15^{\mathrm{cd}}$ \\
\hline & $\mathrm{S}_{1} \mathrm{I}_{3}$ & 77.58 & $7.50^{d}$ & $2.30^{\mathrm{i}}$ & $1.30^{\mathrm{c}}$ & 13.00 & 32.44 & $1.65^{\mathrm{kl}}$ & $2.95^{\mathrm{h}}$ & $35.87^{\text {hi }}$ \\
\hline & $\mathrm{S}_{2} \mathrm{I}_{0}$ & 77.50 & $8.40^{\mathrm{bc}}$ & $2.50^{\text {hi }}$ & $1.40^{\mathrm{b}}$ & 14.00 & 31.67 & $1.83^{\mathrm{ij}}$ & $2.99^{\mathrm{h}}$ & $37.97^{\mathrm{fgh}}$ \\
\hline & $\mathrm{S}_{2} \mathrm{I}_{1}$ & 82.58 & $9.03^{\mathrm{ab}}$ & $3.46^{\mathrm{bc}}$ & $0.53^{\mathrm{i}}$ & 15.92 & 33.37 & $3.55^{\mathrm{b}}$ & $4.50^{\mathrm{a}}$ & $44.10^{\mathrm{abc}}$ \\
\hline & $\mathrm{S}_{2} \mathrm{I}_{2}$ & 81.10 & $9.03^{\mathrm{ab}}$ & $3.17^{\mathrm{de}}$ & $0.93^{\mathrm{f}}$ & 15.50 & 33.45 & $3.00^{\mathrm{d}}$ & $3.90^{\mathrm{cd}}$ & $43.48^{\mathrm{bc}}$ \\
\hline & $\mathrm{S}_{2} \mathrm{I}_{3}$ & 80.50 & $8.90^{\mathrm{ab}}$ & $2.80^{\mathrm{fg}}$ & $1.10^{\mathrm{e}}$ & 13.77 & 33.13 & $1.90^{\mathrm{hi}}$ & $2.90^{\mathrm{h}}$ & $39.58^{\mathrm{ef}}$ \\
\hline & $\mathrm{S}_{3} \mathrm{I}_{0}$ & 79.67 & $8.55^{\mathrm{abc}}$ & $2.95^{\mathrm{ef}}$ & $1.30^{\mathrm{c}}$ & 14.79 & 33.95 & $2.00^{\mathrm{h}}$ & $3.20^{\mathrm{gh}}$ & $38.46^{\mathrm{efg}}$ \\
\hline & $\mathrm{S}_{3} \mathrm{I}_{1}$ & 85.27 & $9.10^{\mathrm{a}}$ & $3.63^{b}$ & $0.47^{\mathrm{i}}$ & 16.47 & 33.22 & $3.70^{\mathrm{a}}$ & $4.36^{\mathrm{ab}}$ & $45.91^{\mathrm{a}}$ \\
\hline & $\mathrm{S}_{3} \mathrm{I}_{2}$ & 83.25 & $9.18^{a}$ & $4.12^{\mathrm{a}}$ & $0.83^{\mathrm{g}}$ & 15.90 & 33.24 & $3.36^{\mathrm{c}}$ & $4.11^{\mathrm{bc}}$ & $44.98^{\mathrm{ab}}$ \\
\hline & $\mathrm{S}_{3} \mathrm{I}_{3}$ & 81.25 & $9.15^{\mathrm{a}}$ & $3.25^{\mathrm{cd}}$ & $1.20^{\mathrm{cd}}$ & 14.83 & 33.51 & $2.20^{\mathrm{g}}$ & $3.25^{\mathrm{gh}}$ & $40.37^{\mathrm{de}}$ \\
\hline & $\mathrm{S}_{4} \mathrm{I}_{0}$ & 76.60 & $8.03^{\mathrm{cd}}$ & $2.26^{\mathrm{ij}}$ & $1.45^{\mathrm{ab}}$ & 13.58 & 32.94 & $1.70^{\mathrm{jk}}$ & $2.90^{\mathrm{h}}$ & $36.96^{\mathrm{ghi}}$ \\
\hline & $\mathrm{S}_{4} \mathrm{I}_{1}$ & 81.25 & $8.93^{\mathrm{ab}}$ & $3.15^{\mathrm{de}}$ & $0.68^{\mathrm{h}}$ & 15.40 & 33.64 & $3.11^{\mathrm{d}}$ & $3.80^{\text {cde }}$ & $45.01^{\mathrm{ab}}$ \\
\hline & $\mathrm{S}_{4} \mathrm{I}_{2}$ & 80.50 & $9.13^{\mathrm{a}}$ & $3.00^{\mathrm{def}}$ & $1.03^{\mathrm{e}}$ & 14.90 & 33.69 & $2.85^{\mathrm{e}}$ & $3.47^{\mathrm{fg}}$ & $42.86^{\mathrm{bc}}$ \\
\hline & $\mathrm{S}_{4} \mathrm{I}_{3}$ & 79.50 & $8.93^{\mathrm{ab}}$ & $2.43^{\text {hi }}$ & $1.20^{\mathrm{d}}$ & 13.50 & 33.53 & $1.85^{\mathrm{i}}$ & $2.90^{\mathrm{h}}$ & $38.95^{\text {efg }}$ \\
\hline & $\mathrm{S}_{1} \mathrm{I}_{0}$ & 74.50 & $7.75^{\mathrm{d}}$ & $2.00^{\mathrm{j}}$ & $1.50^{\mathrm{a}}$ & 13.15 & 33.30 & $1.55^{1}$ & $2.90^{\mathrm{h}}$ & $34.83^{\mathrm{i}}$ \\
\hline & $\begin{array}{c}\text { Level of } \\
\text { significance }\end{array}$ & NS & $*$ & $* *$ & $*$ & NS & NS & $* *$ & $*$ & $* *$ \\
\hline & $\mathrm{S} x$ & 0.66 & 0.20 & 0.09 & 0.03 & 0.42 & 0.53 & 0.04 & 0.11 & 0.73 \\
\hline & $\mathrm{CV}(\%)$ & 3.71 & 6.28 & 6.50 & 11.97 & 4.22 & 1.54 & 4.39 & 3.88 & 2.47 \\
\hline
\end{tabular}

In a column figures having common letter(s) do not differ significant as per DMRT $\quad * *=$ indicates $1 \%$ level of probability, $*=$ indicates $5 \%$ level of probability, NS indicates not significant.
$\mathrm{S} 1=100 \mathrm{~kg}$ ha-1
Io $=$ no irrigation i.e. control
$\mathrm{S} 2=120 \mathrm{~kg}$ ha- 1
I1 = one irrigation given at Crown Root Initiation (CRI) stage
$\mathrm{S} 3=140 \mathrm{~kg}$ ha- 1
$\mathrm{I} 2=$ two irrigation given at CRI and panicle initiation stages
$\mathrm{S} 4=160 \mathrm{~kg}$ ha-1
I3 = three irrigation given at CRI, panicle initiation and grain filling

Table 4. Number of Tillers Thousand grains weight and grains yield wheat as affected by seed Rates and irrigation level

\begin{tabular}{|c|c|c|c|c|}
\hline & Treatments & $\begin{array}{l}\text { Number of } \\
\text { tillers }\end{array}$ & $\begin{array}{l}1000 \text { grains } \\
\text { weight }(\mathrm{g})\end{array}$ & Grains Yield (kg/ha) \\
\hline \multirow{16}{*}{$\begin{array}{l}\text { Shah et al. } \\
(2016)\end{array}$} & Seed rate $(\mathrm{SR}=\mathrm{kgha}-1)$ & & & \\
\hline & $\mathrm{SR} 1=60$ & $299.35 d$ & $39.30 \mathrm{~d}$ & $2437 \mathrm{c}$ \\
\hline & $\mathrm{SR} 2=80$ & $312.90 \mathrm{c}$ & $41.31 \mathrm{c}$ & $2599 \mathrm{bc}$ \\
\hline & $\mathrm{SR} 3=100$ & $317.65 \mathrm{c}$ & $41.95 \mathrm{bc}$ & $2695 b$ \\
\hline & SR4 $=120$ & $346.10 \mathrm{a}$ & $43.15 \mathrm{a}$ & $3160 \mathrm{a}$ \\
\hline & SR5 $=140$ & $331.20 \mathrm{~b}$ & $42.35 \mathrm{~b}$ & $2821 b$ \\
\hline & LSD Value & 10.08 & 0.72 & 232.5 \\
\hline & \multicolumn{4}{|l|}{ Irrigation levels $(\mathrm{IL}=\mathrm{mm})$} \\
\hline & IL1 & $250.30 \mathrm{~d}$ & $38.38 \mathrm{~d}$ & $2417 \mathrm{c}$ \\
\hline & IL2 & $306.55 c$ & $41.43 \mathrm{c}$ & $2650 \mathrm{c}$ \\
\hline & IL3 & $332.70 \mathrm{~b}$ & $42.22 b$ & $2710 \mathrm{~b}$ \\
\hline & IL4 & $362.35 \mathrm{a}$ & $43.19 \mathrm{a}$ & $3130 \mathrm{a}$ \\
\hline & IL5 & $355.30 \mathrm{a}$ & $42.85 \mathrm{a}$ & $2805 b$ \\
\hline & LSD Value & 8.68 & 0.51 & 254.3 \\
\hline & $\begin{array}{l}\text { LSD Value for } \\
\text { interaction }\end{array}$ & & & \\
\hline & SR X IL & $*$ & $*$ & $*$ \\
\hline
\end{tabular}

Means in the same category followed by different letters are significantly different at $\mathrm{P} \geq 0.05$ levels. ${ }^{*}=$ significant 


\section{Conclusions}

Based on different Research findings for irrigated Wheat crop at different parts of the country, site specific and crop based seed rate recommendation should be used for different irrigation conditions like no irrigation, one irrigation two irrigation and three irrigation conditions. Research findings revealed that different seed rate of wheat crop under irrigation condition significantly produced higher yield. Various crops under different agro-ecology and soil type were significantly different in the requirement of seed rate. Therefore, application of higher seed rate for irrigated wheat should be site specific and it should be combined with the amount of irrigation water requirement of the particular area based on the current finding. Moreover, more study on effect of different irrigation water management option should be studied. The findings clearly indicated the interactive effect of the moisture content and amount of seed rate has significant yield advantage over almost all the control treatments.

\section{ACKNOWLEDGMENT}

The authors would like to thank different researchers their materials supporting the review of papers on the interactive effect of irrigation water and seed rate on the productivity of Wheat.

\section{Reference}

CSA (Central Statistical Agency). (1988). Agriculture sample survey Report on Area and production of major Crops (Private peasant holdings, meher season), Addis Ababa, Ethiopia.

CSA (Central Statistical Agency). (2017/18). Agriculture sample survey Report on Area and production of major Crops (Private peasant holdings, meher season), Addis Ababa, Ethiopia, VOLUME I.

FDRE. FDRE; Addis Ababa, Ethiopia: 2013. Ethiopia's Climate Resilient Green Economy: CLIMATE RESILIENT STRATEGY AGRICULTURE. [Google Scholar]

Mann M., Warner J. Research for Ethiopia's Agricultural Policy; Addis Ababa, Ethiopia: 2015. Ethiopian Wheat Yield and Yield Gap Estimation: A Small Area Integrated Data Approach. [PMC free article] [PubMed] [Google Scholar]

Taffesse A., Dorosh P., Asrat S. 2011. Crop Production in Ethiopia: Regional Patterns and Trends ESSP II Working Paper No. 0016. (Addis Ababa, Ethiopia) [Google Scholar]

Yuksel K. (2009). Effect of Planting Methods and Seeding Rate on Grain Yield and Yield Components of Durum Wheat (Triticum durum) in Harran Plain.Journal o Agri Machinery Science 2009, 5(3), 283-289

Wajid Ali Shah, Zafar Hayat, Roohul Amin, Shazma Anwar, Muhammad Islam, Anjum and Ikramullah (2016). Effect of irrigation levels and seed rates on wheat production. Pure and Applied Biology. Vol. 5, Issue 4, pp895-905

http://dx.doi.org/10.19045/bspab.2016.50113

N. A. M. E. Kabir, A. R. Khan, M. A. Islam and M. R. Haque (2009). Effect of seed rate and irrigation level on the performance of wheat cv 